\title{
Chemical Composition and Nutritional Evaluation of Cake Made with Flour Mixture of Pigeonpea and Rice
}

\section{Ferlando Lima Santos*, Wagna Santos, Bruna Machado, Karina Fonseca, Merian Oliveira, Adriana Nascimento}

Federal University of Reconcavo da Bahia (UFRB), Cruz das Almas, Brazil

Email: ^ferlando@ufrb.edu.br

How to cite this paper: Santos, F.L., Santos, W., Machado, B., Fonseca, K., Oliveira, M. and Nascimento, A. (2021) Chemical Composition and Nutritional Evaluation of Cake Made with Flour Mixture of Pigeonpea and Rice. Food and Nutrition Sciences, 12, 1164-1176.

https://doi.org/10.4236/fns.2021.1211085

Received: July 4, 2021

Accepted: November 26, 2021

Published: November 29, 2021

Copyright $\odot 2021$ by author(s) and Scientific Research Publishing Inc. This work is licensed under the Creative Commons Attribution International License (CC BY 4.0).

http://creativecommons.org/licenses/by/4.0/

(c) (i) Open Access

\begin{abstract}
This study aimed to develop and characterize a cake based on a flour mixture of pigeonpea and rice. Four cake formulations of different percentages of pigeonpea flour $(\mathrm{PF})$ and Rice Flour (RF) $(0 \% \mathrm{PF}+100 \% \mathrm{RF}, 10 \% \mathrm{PF}+90 \%$ RF, $20 \% \mathrm{PF}+80 \% \mathrm{RF}, 30 \% \mathrm{PF}+70 \% \mathrm{RF})$ were developed based on a traditional formulation. Microbiological, physicochemical and sensory evaluations were performed. The tasters preferred the mix formulation containing 30\% pigeonpea and $70 \%$ rice $(\mathrm{p}<0.05)$. This formulation presented adequate physicochemical and microbiological characteristics. The study also showed $90 \%$ acceptance and $70 \%$ purchase intention by the tasters. It is concluded that the use of a flour mixture of pigeonpea and rice allows an innovative, nutritious product, with good acceptance and technological potential. This product meets the needs of the food industry, such as: 1) it is gluten-free; 2) contributes for the adoption of healthy eating habits; 3 ) promotes family farming; and 4) stimulates the consumption of regional vegetables that can be incorporated into school meals menus, rescuing the consumption habits of rice and beans and eventually valuing the traditional Brazilian diet. It is worth noting the low lipid, high fiber, iron and zinc content characteristic of the developed product.
\end{abstract}

\section{Keywords}

Legumes, Sensory Evaluation, Food Technology

\section{Introduction}

Grains legumes are a group of food with great relevance in the national and international scenario due to their nutritional and socioeconomic value. In terms 
of variety, Brazil is the third producer of legumes worldwide, accounting for $12 \%$ of the world's production [1]. In Brazil, family farming is the main staple food supplier and plays a decisive role in food cultivation for the domestic market. According to the 2011 Agricultural Census, family farming is responsible for $83 \%$ of the production of beans consumed by the population of the state of Bahia [2].

The pigeonpea (Cajanus cajan L. Millsp) is a legume (family Fabaceae) brought from India to Brazil and Guianas, where it has gained the status of an important source of human food. It is popularly known as "guandu", "guando", "gandu", "andu" or pigeon pea, depending on the region where it is cultivated [3].

From the nutritional point of view, this legume is a source of proteins, carbohydrates, vitamins and minerals, (calcium, iron, phosphorus, potassium, magnesium, zinc and manganese). It contains considerable amounts of fiber and is rich in lysine, phenylalanine, valine, arginine, aspartic acid and glutamic acid; it is, however, deficient in methionine and cysteine [4]. Pigeon pea also presents medicinal action against Sickle cell disease by inhibiting sickling of red blood cells [5].

Rice (Oryza sativa L.) is also a staple food in many countries and represents a source of vitamins, mainly of the B complex, fibers and minerals [6]. Legumes are relatively low in protein, hence if consumed as the only source of protein, can lead to food deficiency. The combination of pigeonpea, rich in lysine and poor in sulfur amino acids (methionine and cysteine) with rice, deficient in lysine but rich in methionine, offers a supply of proteins of higher nutritional value, with a more suitable amino acids composition to human needs [7].

Thus, the incorporation of rice flour into recipes is an excellent strategy, adding functional characteristics to gluten-free products [8]. One such food option is cake, which consumption and commercialization has been growing in Brazil [9].

It is worth noticing that, according to data from the Household Budget Survey (HBS) of the Brazilian Institute of Geography and Statistics (IBGE), between 2002 and 2009 , there was a reduction of $40.5 \%$ in the participation of rice and of 26.4\% of beans in the household diet of Brazilians [10]. The 2014 Food Guide for the Brazilian Population recommends a proportion of 2:1 in the daily consumption of rice and beans. This recommendation favors an ideal combination in terms of essential amino acids and acts to correct nutritional problems and to foster the traditional Brazilian diet, which is based on the combination of cereals and legumes (rice and beans), fruits and vegetables [11].

Attentive to this reduction in the consumption of rice and beans by Brazilians, the present study developed a cake recipe with bean and rice flours and performed sensorial and physicochemical analyses of the product. The bean used is produced by family farms, thus valuing the traditional Brazilian diet.

\section{Material and Methods}

\subsection{Sampling and Acquisition of Pigeonpea Flour (PF)}

The grains of the legume Pigeonpea (immature seed) were obtained from family 
farmers of the city of Santo Antônio de Jesus-Bahia. The grains were selected, washed and bleached in the Food Technology Laboratory at the University of Reconcavo da Bahia.

To obtain the flour, the pigeonpea grains were dried in an oven (Biopar, Porto Alegre, Brazil) at $50^{\circ} \mathrm{C}$ for $30 \mathrm{~h}$ and ground in a food processor (Philips, São Paulo, Brazil). The powder was then sieved using a $21 \mathrm{~mm}$ mesh, packed in plastic containers, and stored at $25^{\circ} \mathrm{C}$.

\subsection{Technological Functional Properties of the Pigeonpea Flour}

To determine the gelling capacity of the Pigeonpea Flour (PF), we adapted the method proposed in Coffmann and Garcia [12]. The water absorption index (WAI) was determined according to Beuchat [13] and the water solubility index (WSI) was obtained based on Okezie and Bello [14].

\subsection{Cake Formulations}

Based on previous laboratory results, we adapted a traditional recipe using four different percentages of PF and Rice Flour (RF) (0\% PF + 100\% RF, 10\% PF + $90 \% \mathrm{RF}, 20 \% \mathrm{PF}+80 \% \mathrm{RF}, 30 \% \mathrm{PF}+70 \% \mathrm{RF}$ ) (Table 1).

Initially, all ingredients were weighed in a semi-analytical balance (Marte, São Paulo, Brazil). Eggs, margarine and sugar were mixed with a mixer (Arno, São Paulo, Brazil). Then, a mixture of RF and PF was added to the dough, which was homogenized for $15 \mathrm{~min}$. Finally, milk, salt and baking powder were added gradually. The dough was poured into an aluminum tray, greased with margarine and sparkled with RF, and baked in an oven (Metalmaq, Duque de Caxias, Brazil) preheated at $180^{\circ} \mathrm{C}$ for $1 \mathrm{~h}$.

\subsection{Sensory Evaluation}

Ethical clearance for this study was granted by the Ethics Committee of the University of Reconcavo da Bahia (Process n. 31797114 00000056). All participants signed the Informed Consent Form (ICF).

\section{Ranked-preference test}

Table 1. Cake recipes.

\begin{tabular}{ccccc}
\hline Ingredients $(\mathrm{g})$ & Standard & $10 \%$ & $20 \%$ & $30 \%$ \\
\hline Pigeonpea flour & ---- & 29.65 & 58.48 & 87.73 \\
Rice flour & 292.44 & 262.80 & 237.95 & 204.71 \\
Margarine & 87.87 & 87.87 & 87.87 & 87.87 \\
Sugar & 150.00 & 150.00 & 150.00 & 150.00 \\
Egg & 110.12 & 110.12 & 110.12 & 110.12 \\
Wholemilk & 189.52 & 189.52 & 189.52 & 189.52 \\
Bakingpoder & 5.00 & 5.00 & 5.00 & 5.00 \\
Salt & 0.40 & 0.40 & 0.40 & 0.40 \\
\hline
\end{tabular}


The test was conducted in individual booths with 40 untrained tasters who were offered four cake samples, in random order, displayed on disposable dishes coded with three-digits codes. The tasters were asked to taste the four samples from left to right and to order them from best to worst, according to their preference. Results were analyzed by Friedman's non-parametric test at the 5\% significance level [15].

\section{Acceptance test and purchase intent}

The acceptance and purchase intent tests with potential consumers were conducted based on the results obtained in the previous test, which was used to select the most preferred sample. The test was conducted with 100 untrained tasters (employees, teachers and students of the University).

The 9-point hedonic scale was used in the acceptance test, that ranged from disliked extremely (1) to liked extremely (9). The same scale was used to evaluate flavor, color, texture and overall acceptance.

A structured 5-point scale was adopted in the purchase intention test, that ranged from certainly would not buy (1) to certainly would buy (5) [15].

\subsection{Physicochemical Evaluation}

The cake selected according to the ranked-preference test was characterized in relation to moisture [16], water activity (Decágono Lab Master, Novasina ${ }^{\circledR}$ ), pH, total titratable acidity, proteins, iron, zinc [17], lipids [18], and fibers [19]. Carbohydrates were determined by difference and total caloric value by the Atwater System [20]. Color parameters $\left(a^{*}, b, L^{*}, C^{*}\right.$ and $h$ ) were determined by the CIELAB System. All evaluations were performed in triplicates.

\subsection{Microbiological Evaluation}

Samples were analyzed for total and thermotolerant coliforms at $45^{\circ} \mathrm{C}$, detection of Salmonella sp., and yeasts and molds, according to the methodology described in [21].

\section{Results and Discussion}

\subsection{Functional and Technological Properties}

WAI is a parameter that indicates the integrity of starch granules and the ability to absorb water when gelatinized [22]. The average WAI found in our sample was $3.8 \mathrm{~g} / \mathrm{g}$ (Table 2). In the industry, this parameter is essential for bakery products, because it allows the maintenance of moisture and softness of the final product [23].

Table 2. Functional properties of PF.

\begin{tabular}{cc}
\hline Parameters & Scores \\
\hline Water Absorption Index (gel/g) & $3.8 \pm 0.39$ \\
Gelification capacity (\%) & 12 \\
Water Solubility Index (\%) & $8 \pm 3.46$ \\
\hline
\end{tabular}


Regarding gelling ability, gel formation was observed at a concentration of $12 \%$ of PF. Cowpea flour started to form gel at a concentration of 4\% [24]. Gel formation is associated with starch gelatinization, mainly provided by the amylose content, and by the ability of proteins to form three-dimensional networks capable of holding water [25].

The Water Solubility Index (WSI) of PF is $8 \%$ (Table 2), lower than those found in [26] for five commercial cultivars of cowpea, that ranged from $17 \%$ to $23 \%$. Another study found higher values, ranging from $9.22 \%$ to $14.83 \%$, when evaluating the absorption and solubilization properties of mixed flour extrudates [27]. The authors explained the high values by the mixture of flours whose solubility depends not only on the starch content, but also on the interaction with other nutrients such as proteins and their structural modifications post gelatinization.

It is worth mentioning that the solubility of a product depends on its chemical constitution, structural conformation and the presence of polar amino acids. Globulins are present in higher concentration in beans, mainly in the cotyledon. Because of their partial solubility in water, they are easily denatured, which can directly influence the final solubility. Moreover, the higher the proportion of amylose in the starch granules of mature beans, the more abundant the water connections [28]. However, it is worth stressing that the flours used in the present study were obtained from immature grains with tegument, which may have influenced our results.

\subsection{Sensory Evaluation}

\section{Ranked-preference test}

There was no significant difference between the samples containing 10\%, 20\% and 30\% PF and the control cake $(\mathrm{P}<0.05)$ (Table 3). Based on these results, $\mathrm{PF}$ $30 \%$ sample was selected for the acceptance test, physicochemical and microbiological analysis due to its highest concentration of PF and, consequently, highest nutritional value.

The ages of participants of the acceptance test were distributed as: from 15 to 20 years old (25\%), from 21 to 29 years old (43\%), from 30 to 39 years old (21\%), from 40 to 49 years old (9\%) and from 50 to 59 (2\%). Most participants were females $(71 \%)$.

Table 3. Ranked-preference test.

\begin{tabular}{cc}
\hline Sample (\%) & Scores \\
\hline CF & $95^{\mathrm{a}}$ \\
PF10 & $100^{\mathrm{a}}$ \\
PF20 & $100^{\mathrm{a}}$ \\
PF30 & $100^{\mathrm{a}}$ \\
\hline
\end{tabular}

$\mathrm{CF}=$ Rice flour cake used as control $(0 \% \mathrm{PF}+100 \% \mathrm{RF}) ; \mathrm{PF} 10=10 \% \mathrm{PF}+90 \% \mathrm{RF}$; PF20 $=20 \% \mathrm{PF}+80 \% \mathrm{RF} ; \mathrm{PF} 30=30 \% \mathrm{PF}+70 \% \mathrm{RF}$. Scores followed by the same letter did not differ from each other at the $5 \%$ of significance. Total taste score attributed by tasters. 
Among the studied population, $32 \%$ consume cake on a monthly basis, $20 \%$ on a fortnightly basis, $1 \% 2$ to 3 times a week, and $26 \%$ once a week. According to this, consumption of cakes by this population is not usual. The tasters approved the $\mathrm{PF} 30 \%$ recipe with $90 \%$ of positive acceptance, i.e., scores in the acceptance zone (6 to 9) (Figure 1(A)).

These results resemble those found in Borges et al. [29], when partially replacing wheat flour with oat flour. They found a better acceptance of the formulation containing $30 \%$ of oat flour in comparison with $15 \%$ and $45 \%$. Cowpea flour (CF) was also used in enriched baked goods such as biscuit and Brazilian rolls $(10 \%, 20 \%$ and $30 \%$ of $\mathrm{CF})$, with a better acceptance of the recipe with $10 \%$ CF (84.4\%) [30]. A cake recipe developed in [31] with $20 \%$ CF plus $20 \%$ flour without teguments and with teguments obtained $89.2 \%$ and $85.1 \%$ of acceptance, respectively.

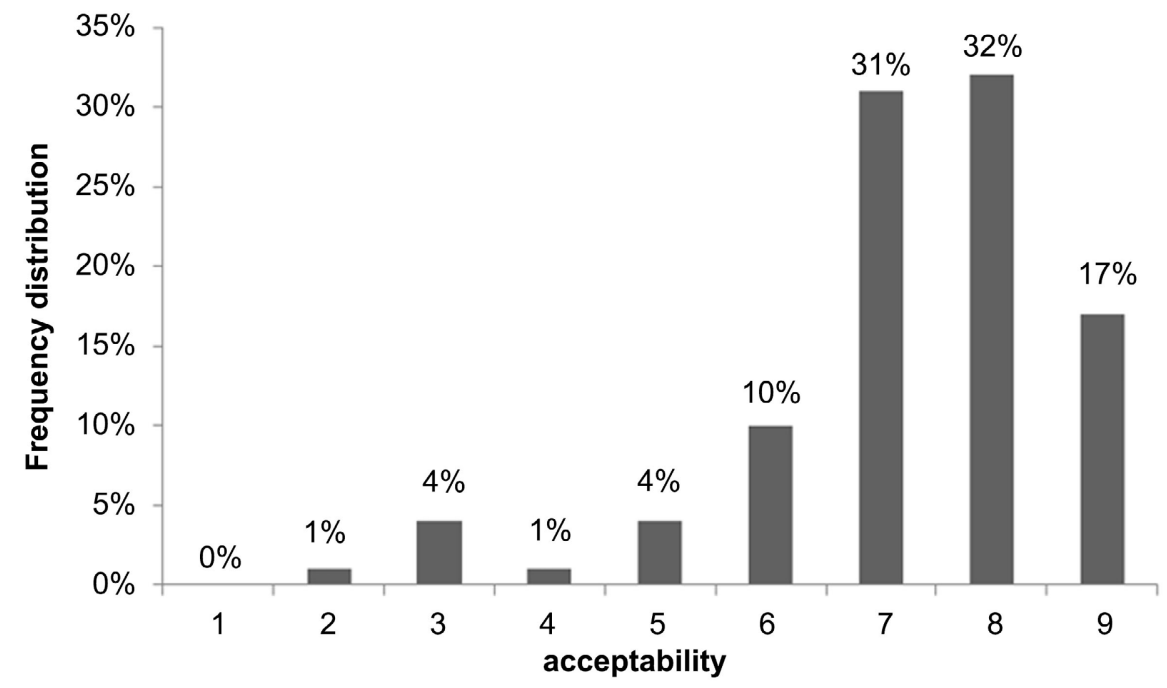

(A)

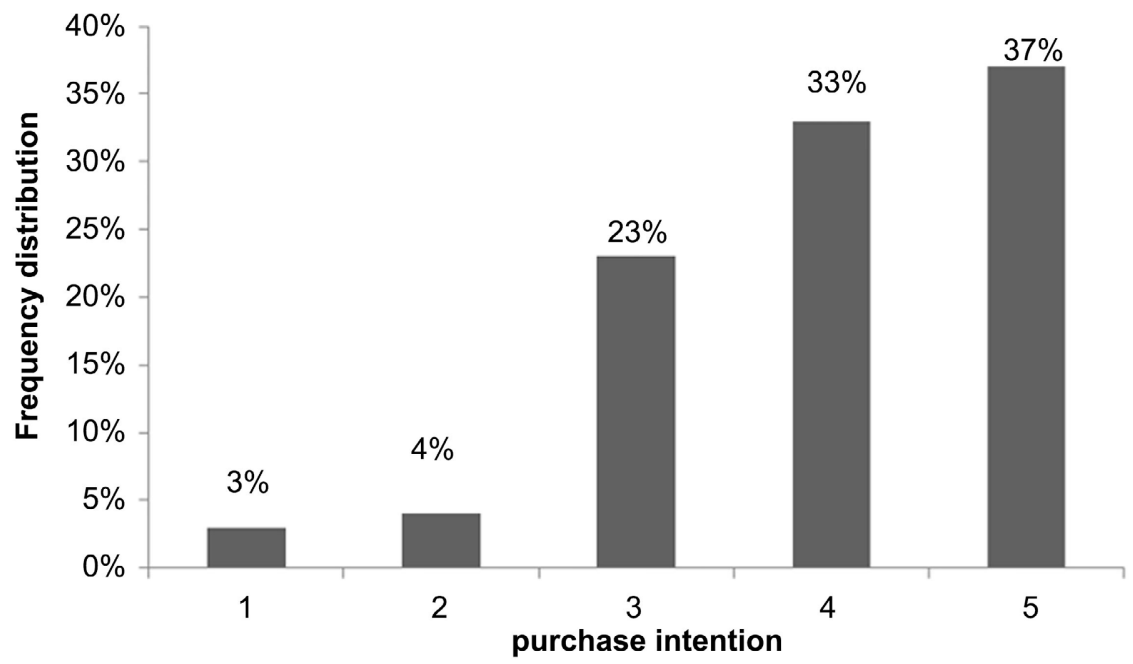

(B)

Figure 1. Frequency distribution of scores given for acceptability (A) and (B) purchase intention. 
It is worth noting that gluten-free products (GFP) are currently found in markets, but they are often not well accepted by consumers. Furthermore, many GFP still present some nutritional imbalances and inadequacies and are costly in comparison to products that contain gluten. This makes GFP hardly accessible to economically disadvantaged populations [32] [33].

Therefore, the incorporation of rice flour in product formulations is an excellent strategy to confer functional characteristics to gluten-free products without increasing the final product's cost, meeting the needs of individuals with nutritional diseases such as celiac disease and consumers who are increasingly looking for healthier foods [8].

The purchase intention test obtained $70 \%$ of positive intention-would probably buy or would certainly buy the product (values 4 and 5). The negative intention, that is, people who certainly or probably would not buy (values 1 and 2) totaled $7 \%$ (values 1 and 2), while $23 \%$ of testers were not sure (value 3) (Figure $1(B))$.

According to [34], the consumer's intention to buy a food product is guided by a very complex process, influenced by different variables such as price, convenience and marketing, but the sensorial attributes of the product are essential to confirm the decision.

Sensorial attributes of flavor, color, texture and overall acceptance obtained averages of 7.17,6.79, 6.41,7.34, respectively, varying between the terms "liked slightly" and "liked moderately". Results indicate, in general, good sensorial acceptance of the cake. A study on the acceptability of biscuits prepared with cowpea, andu and mangalo beans, considered the same attributes and obtained lower averages: 5.16, 6.47, 6.85, 5.85, respectively [35].

Results indicate that the product presents acceptable sensorial characteristics, showing the viability of the use of RF and $\mathrm{CF}$ in the development of cakes. In addition to the incorporation of raw materials from $\mathrm{RF}$ in food processing, it can be included in school menus, according to the guidelines of the National School Feeding Program [36]. Additionally, the proposed flour mixture meets the demand for celiac patients (gluten-free foods) and represents a complementary/ alternative option for the treatment of patients with sickle cell disease through the improvement of their prognosis and health status [5]. Moreover, since the annual per capita household consumption of beans and rice has dropped in Brazil, it promotes their consumption in the daily diet as recommended by the Brazilian Food Guide [11].

\subsection{Physicochemical and Microbiological Evaluations}

Results of the centesimal analysis of the PF30\% formulation are shown in Table 4.

The cake can be classified as of low acidity, since its $\mathrm{pH}$ is higher than 4.5 (Table 4). Therefore, it is extremely important to control this product characteristic during storage [37]. The average acidity of the product is 0.94 . Cake recipes 
Table 4. Physicochemical analysis of the cake made with flour mixture of rice and Pigeon flour.

\begin{tabular}{cc}
\hline Parameters & Average \pm SD \\
pH & $7.08 \pm 0.02$ \\
Acidity & $0.94 \pm 0.13$ \\
Water activity & $0.92 \pm 0.01$ \\
Moisture & $27.25 \pm 3.93$ \\
Fibers (\%) & $12.53 \pm 1.70$ \\
Lipids (\%) & $6.44 \pm 0.37$ \\
Proteins (\%) & $9.85 \pm 0.10$ \\
Ashes (\%) & $6.75 \pm 0.75$ \\
Carbohydrates (\%) & $37.18 \pm 4.87$ \\
Iron (mg/100g) & $3.50 \pm 0.10$ \\
Zinc (mg/100g) & $2.80 \pm 0.30$ \\
Energy value (kcal/100g) & $246.10 \pm 4.46$ \\
\hline
\end{tabular}

developed with $7 \%$ and $30 \%$ of watermelon inner skin flour found "after cooking" $\mathrm{pH}$ of 7.65 and 6.66, respectively [38]. However, the formulations showed higher acidity (1.0 and 4.56) than the product developed in the present study.

The average Water Activity (WA) of the product is 0.92 , slightly higher than that found by other authors. One study [39] found WA ranging from 0.716 to 0.918 for different types of chocolate cake toppings, while [40] obtained average values ranging from 0.880 to 0.900 , when evaluating the influence of oat and fat contents on the technological and functional characteristics of cakes. The moisture content of the studied product was $27.25 \%$. This value is lower than the one found in [41], for cakes made with white bean flour (32.83\%). In the study mentioned, it was observed that high levels of moisture are found in cakes with dietary fiber, which is explained by the property of the fibers to retain and maintain water in their structure during the cooking process. The content of fibers observed in our product is 12.53 , which is much higher than the values found in [41] in cakes containing $50 \%$ of white bean flour (5.18\%).

This product showed lower lipid content (6.44) when compared to the findings in [37], which evaluated 3 cake formulations using $8.87 \%$ wheat flour (F1) and mixed wheat flour substitute as follows: $12.13 \%(\mathrm{~F} 2), 10.09 \%$ (F3).

The carbohydrate content of our product is $37.18 \%$, which is similar to that found in [42] for standard and optimized cakes $(59.32 \%$ and $59.30 \%$, respectively). Regarding protein content, the product is composed of $9.85 \%$ of this macronutrient, which is higher than that reported in [38], which found $6.47 \%$ of protein in a cake made with wheat flour. In addition to the increase in the protein content, the partial substitution of rice flour by bean flour improves the product's amino acid profile [11]. 
Most of the studies cited here lack the determination of micronutrients levels. Here, we quantified two important micronutrients, iron and zinc, and compared our results with a few existing studies. The iron content of our product is 3.5 $\mathrm{mg} / 100 \mathrm{~g}$, which is higher than that found in [43], for cakes made with refined wheat flour $(0.14 \mathrm{mg})$. The zinc content is $2.80 \mathrm{mg} / 100 \mathrm{~g}$. Biscuits and Brazilian rolls with $10 \%$ of cowpea flour presented $0.70 \mathrm{mg} / 100 \mathrm{~g}$ and $0.42 \mathrm{mg} / 100 \mathrm{~g}$ of zinc, respectively [31].

The addition of PF to cake recipes can increase the iron and zinc intake. This makes it a good option to be included in school meals, benefiting mainly the children, who are the most affected by micronutrient deficiency.

The iron and zinc content of our product is within the recommendations of the Dietary Reference Intakes (DRI) for children between 4 and 8 years of age. Iron and zinc vary equally in 35\%. For children between 9 and 13 years of age, our product account for $43.75 \%$ and $35 \%$ of the DRI for iron and zinc, respectively [44].

Based on these results, we believe that the addition of PF to cakes can increase the intake of iron and zinc and, hence, it is worth including in the school feeding program. Schoolers represent a group of great vulnerability due to their rapid growth, physiological and immunological immaturity and inadequacies in nutrient intake, which may compromise their nutritional status and lead to nutritional deficiencies or excesses [45].

Regarding energetic value, the cake has $289.69 \mathrm{kcal}$, a result lower than the one (321.3 kcal) found in [37].

Regarding the chromaticity parameters, we found $\mathrm{a}^{*}=2.77 \pm 0.170$ and $\mathrm{b}^{*}=$ $18.65 \pm 0.421$, luminosity $\left(L^{*}\right)=53.223 \pm 0.456, C^{*}=18.860 \pm 0.407$ and $h=$ $51.547 \pm 0.633$. These last two parameters indicate that the product is yellowish, with low saturation. The addition of $\mathrm{PF}$ reduced $\mathrm{L}^{*}$ and increased $\mathrm{b}^{*}$, indicating a shift from white to yellow. Higher $\mathrm{L}^{*}$ and $\mathrm{a}^{*}$ values and lower $\mathrm{b}^{*}$ were found in cakes made with rice bran flours and extruded bean bread flour [46].

According to the microbiological evaluation, the cake sample complies with the standards established by the Brazilian Legislation [47], for Salmonella $s p$., contamination by yeasts and molds $(<1 \log \mathrm{CFU} / \mathrm{g})$, Total Coliforms $(<3$ $\mathrm{NMP} / \mathrm{g})$ and Coliforms at $45^{\circ} \mathrm{C}(<3 \mathrm{NMP} / \mathrm{g})$.

\section{Conclusion}

This work found that it is possible to incorporate RF and PF in the development of baked goods, creating a product with adequate sensorial, microbiological and physicochemical characteristics. The developed cake meets the needs of the food industry as a gluten-free, affordable, nutritionally rich product with organoleptic characteristics that favors consumer's taste. It also incorporates products from family farming into the food processing and stimulates the adoption of healthy eating habits. The studied flour mixture formulation can be included into menus of School Meals Programs. 


\section{Acknowledgements}

The authors are thankful to $\mathrm{CNPq}$ for their financial support.

\section{Conflicts of Interest}

The authors declare no conflicts of interest regarding the publication of this paper.

\section{References}

[1] Wander, A.E. (2017) Cenário Nacional e novas oportunidades de Mercado. Embrapa Arroz e Feijão, Goiás.

https://www.alice.cnptia.embrapa.br/bitstream/doc/1078887/1/CNPAF2017conafep 292.pdf

[2] Brasil (2014) Plano Safra 2014-2015: Agricultura familiar na Bahia, da assistência técnica à comercialização. Ministério da Agricultura Pecuária e Abastecimento, SEAGRI/SUAF.

[3] Embrapa (2012) Informações técnicas para o cultivo do feijoeiro-comum na Região Central Brasileira: 2012-2014. Embrapa, Arroz e Feijão, Santo Antônio de Goiás. http://www.cnpaf.embrapa.br/transferencia/informacoestecnicas/publicacoesonline /seriedocumentos 272.pdf

[4] Azevedo, R.L., Ribeiro, G.T. and Azevedo, C.L.L. (2010) Feijão guandu: Uma planta multioso. Revista Fapese, 3, 81-86.

[5] Cordovil, K., Cople-Rodrigues, C.S., Santos, I.N., et al. (2015) Revisão das Propriedades Medicinais de Cajanus cajanna Doença Falciforme. Revista Brasileira de Plantas Medicinais, 17, 1169-117. https://doi.org/10.1590/1983-084x/14 139

[6] Walter, M., Marchezan, E. and Avila, L.A. (2008) Arroz: Composição e características nutricionais. Ciência Rural, 38, 1184-1192. https://doi.org/10.1590/S0103-84782008000400049

[7] Mesquita, F.R., Corrêa, A.D., Abreu, C.M.P., et al. (2007) Linhagens de feijão (phaseolus vulgaris L.): Composição química e digestibilidade protéica. Ciência e Agrotecnologia, 31, 1114-1121. https://doi.org/10.1590/S1413-70542007000400026

[8] Mariani, M., Oliveira, V.R., Faccin, R., et al. (2015) Elaboração e avaliação de biscoitos sem glúten a partir de farelo de arroz e farinhas de arroz e de soja. Brazilian Journal of Food Technology, 18, 70-78. https://doi.org/10.1590/1981-6723.6514

[9] Zavareze, E.R., Moraes, K.S. and Salas-Mellado, M.L.M. (2010) Qualidade tecnológica e sensorial de bolos elaborados com soro de leite. Ciência e Tecnologia de Alimentos, 30, 100-105. https://doi.org/10.1590/S0101-20612010000100015

[10] IBGE (2011) Pesquisa de Orçamentos Familiares 2008-2009 POF, Rio de Janeiro. https://biblioteca.ibge.gov.br/visualizacao/livros/liv50063.pdf

[11] Brasil (2014) Guia alimentar para a população brasileira. Ministério da Saúde, Brasília.

[12] Coffmann, C.W. and Garcia, V.V. (1977) Functional Properties and Amino Acid Content of a Protein Isolate from Mung Bean Flour. Journal of Food Technology, 12, 473-484. https://doi.org/10.1111/j.1365-2621.1977.tb00132.x

[13] Beuchat, L.R. (1977) Functional and Electrophoretic Characteristics of Succinylated Peanut Flour Protein. Journal of Agricultural and Food Chemistry, 25, 258-261. https://doi.org/10.1021/jf60210a044

[14] Okezie, B.O. and Bello, A.B. (1988) Physicochemical and Functional Properties of 
Winged Bean Flour and Isolate Compared with Soy Isolate. Journal of Food Science, 53, 450-454. https://doi.org/10.1111/j.1365-2621.1988.tb07728.x

[15] Meilgaard, M.R., Civille, G.V. and Carr, B.T. (2007) Sensory Evaluation Techniques. CRC Press, Boca Raton. https://doi.org/10.1201/b16452

[16] AOAC (1997) International Official Methods of Analysis. Association of Official Analytical Chemists, Arlington.

[17] IAL (2008) Métodos físico-químicos para análise de alimentos. Instituto Adolfo Lutz, São Paulo.

[18] Bligh, E.G. and Dyer, W.J. (1959) A Rapid Method of Total Lipid Extraction and Purification. Canadian Journal of Biochemistry and Physiology, 37, 911-917. https://doi.org/10.1139/059-099

[19] Van Soest, P.J., Robertson, J.B. and Lewis, B.A. (1991) Methods for Dietary Fiber, Neutral Detergent Fiber and Non-Starch Polysaccharides in Relation to Animal Nutrition. Journal of Dairy Science, 74, 3583-3597. https://doi.org/10.3168/jds.S0022-0302(91)78551-2

[20] Watt, B. and Merril, A.L. (1963) Composition of Foods: Raw, Processed, Prepared. U.S. Department of Agriculture, Agriculture Handbook No. 8.

[21] APHA (2001) Committee on Microbiological for Foods. Compendium of Methods for the Microbiological Examination of Foods. American Public Health Association, Washington DC.

[22] Silva, E.M.M., Ascheri, J.L.R., Ascheri, D.P.R., et al. (2013) Efeito da extrusão termoplástica nas características de viscosidade de pasta, solubilidade e absorção de água de farinhas pré-gelatinizadas de milho e feijão carioca. Boletim CEPPA, 31, 99-114. https://doi.org/10.5380/cep.v31i1.32707

[23] Wang, K., Lu, F., Li, Z., et al. (2017) Recent Developments in Gluten-Free Bread Baking Approaches: A Review. Food Science and Technology, 37, 1-9. https://doi.org/10.1590/1678-457x.01417

[24] Pereira, R.N. (2013) Caracterização bioquímica, nutricional efuncional de Genótipo selite de feijão caupi Vigna unguiculata (L.) Walp. Dissertação, Universidade Federal do Ceará, Fortaleza.

[25] Singh, N., Singh, J., Kaur, L., et al. (2003) Morphological, Thermal and Rheological Properties of Starches from Different Botanical Sources. Food Chemistry, 81, 219-231. https://doi.org/10.1016/S0308-8146(02)00416-8

[26] Rios, M.J.B.L., Lugo, L.M.N., Sampaio, J.P.M., et al. (2016) Parâmetros físicos de farinhas de cinco cultivares de feijão-caupi [Vigna unguiculata (L.) Walp.]. IV Congresso Nacional de Feijão-Caupi, Embrapa, Sorriso.

[27] Moura, L.S.M., Ascheri, J.L.R., Silva, C.C.O., et al. (2011) Propriedades de absorção e solubilização de extrudados de farinha mista de feijão, milho e arroz biofortificados. IV Reunião de biofortificação, Teresina.

[28] Salgado, S.M., Guerra, N.B., Andrade., S.A.C., et al. (2005) Caracterização físico-química do grânulo do amido do feijão caupi. Revista Ciência e Tecnologia de Alimentos, 25, 525-530. https://doi.org/10.1590/S0101-20612005000300022

[29] Borges, J.T.S., Pirozi, M.R., Lucia, S.M.D., et al. (2006) Utilização de farinha mista de aveia e trigo na elaboração de bolos. Boletim CEPPA, 24, 145-162. https://doi.org/10.5380/cep.v24i1.5286

[30] Frota, K.M.G., Morgano, M.A., Silva, M.G., et al. (2010) Utilização da farinha de feijão-caupi (Vigna unguiculata L. Walp) na elaboração de produtos de panificação. Ciência e Tecnologia de Alimentos, 30, 44-50. 
https://doi.org/10.1590/S0101-20612009005000003

[31] Nascimento, A.S., Oliveira, M.C., Portela, A.C.C., et al. (2017) Análise sensorial de bolos desenvolvidos com farinha de feijão da agricultura familiar. VIII Congresso latino americano, XIV Congresso brasileiro de higienistas de alimentos e VI encontro do sistema brasileiro de inspeção de produtos de origem animal. Revista de Higiene Alimentar, 31, 266-267.

[32] Missbach, B., Schwingshackl, L., Billmann, A., et al. (2015) Gluten-Free Food Database: The Nutritional Quality and Cost of Packaged Gluten-Free Foods. PeerJ, 3, .1-18. https://doi.org/10.7717/peerj.1337

[33] El Khoury, D., Balfour-Ducharme, S. and Joye, J.I. (2018) A Review on the Gluten-Free Diet: Technological and Nutritional Challenges. Nutrients, 10, 1410. https://doi.org/10.3390/nu10101410

[34] Walter, E.H.M., Fontes, L.C.B., Osawa, C.C., et al. (2010) A influência de coberturas comestíveis na aceitação sensorial e intenção de compra de bolos de chocolate. Ciência e Tecnologia de Alimentos, 30, 335-341.

https://doi.org/10.1590/S0101-20612010000200008

[35] Farias, L.C., Santos, W.P.C., Benevides, C.M.J., et al. (2016) Avaliação da aceitabilidade de biscoitos elaborados com os feijões caupi, andu e mangalô. Sociedade Brasileira de Ciência e Tecnologia de Alimentos. Anais XXV Congresso Brasileiro de Ciência e Tecnologia de Alimentos, Gramado.

[36] Ferigollo, D., Kirsten, V.R., Heckler, D., et al. (2017) Aquisição de produtos da agricultura familiar para alimentação escolar em municípios do Rio Grande do Sul. Revista de Saúde Pública, 51, 1-10. https://doi.org/10.1590/s1518-8787.2017051006648

[37] Silva, L.A.A., Freitas, F.V., Vieira, T.S., et al. (2017) Utilização de ingredientes sucedâneos ao trigo na elaboração de bolos sem glúten. Revista do Instituto Adolfo Lutz, 76, 1-8.

[38] Guimaraes, R.R., Freitas, M.C.J. and Silva, V.M. (2010) Bolos simples elaborados com farinha da entrecasca de melancia (Citrullus vulgaris, sobral): Avaliação química, física e sensorial. Ciência e Tecnologia de Alimentos, 30, 354-363.

https://doi.org/10.1590/S0101-20612010000200011

[39] Osawa, C.C., Fontes, L.C.B., Miranda, E.H.W., et al. (2009) Avaliação físico-química de bolo de chocolate com coberturas comestíveis à base de gelatina, ácido esteárico, amido modificado ou cera de carnaúba. Ciência e Tecnologia Alimentos, 29, 92-99. https://doi.org/10.1590/S0101-20612009000100015

[40] Gutkoski, L.C., Teixeira, D.M.F., Durigon, A., et al. (2009) Influência dos teores de aveia e de gordura nas características tecnológicas e funcionais de bolos. Ciência e Tecnologia de Alimentos, 29, 254. https://doi.org/10.1590/S0101-20612009000200003

[41] Carvalho, V.S., Damiani, C., Brandão, C.C., et al. (2011) Avaliação da composição química do bolo elaborado com farinha de feijão branco. Anais Congresso Nacional de pesquisa de feijão, Goiânia.

[42] Silva, I.C.V., Santos, A.A.O., Alves, A.R., et al. (2012) Fécula de mandioca e farinha de albedo de laranja na formulação de bolos de chocolate. Revista do Instituto Adolfo Lutz (impresso), 71, 111-117.

[43] Pinki, A. and Pratima, A. (2014) Sensory and Nutritional Evaluation of Value Added Cakes Formulated by Incorporating Beetroot Powder. International Journal of Food and Nutritional Sciences, 3, 145-148.

[44] IOM (2002) Dietary Reference Intakes for Energy, Carbohydrate, Fiber, Fatty Acids, 
Cholesterol, Proteinand Aminoácidos. National Academy Press, Washington DC.

[45] Carvalho, C.A., Fonsêca, P.C.A., Priore, S.E., et al. (2015) Consumo alimentar e adequação nutricional em crianças brasileiras: Revisão sistemática. Revista Paulista de Pediatria, 33, 211-221. https://doi.org/10.1016/j.rpped.2015.03.002

[46] Gomes, L.O.F., Santiago, R.A.C., Koakuzu, S.N., et al. (2014) Estabilidade microbiológica e físico-química de misturas para bolo sem glúten e qualidade dos bolos prontos para consumo. Brazilian Journal of Food Technology, 17, 283-295. https://doi.org/10.1590/1981-6723.0914

[47] Brasil (2001) Resolução RDC nº. 12 de 02 de janeiro de 2001. Agência Nacional de Vigilância Sanitária, Ministério da Saúde, ANVISA/MS. 